\title{
PERANCANGAN APLIKASI DOCUMENT MANAGEMENT SYSTEM BERBASIS WEB UNIVERSITAS NASIONAL DENGAN METODE WATERFALL
}

\author{
Cut Dinda Rizki Amirillah ${ }^{1}$, Septi Andryana ${ }^{2}$, Benrahman ${ }^{3}$ \\ Program Studi Informatika, Universitas Nasional \\ cutdinda99@gmail.com
}

Submitted April 30, 2020; Revised June 16, 2020; Accepted July 7, 2020

\begin{abstract}
Abstrak
Salah suatu aset yang sangat penting dalam mendukung setiap program kerja yang dilaksanakan pada civitas Universitas Nasional adalah manejem dokumen. Dalam proses saat ini dipastikan organisasi akan menghasilkan data atau dokumen yang tidak sedikit dengan berbagai macam kriteria. Banyaknya dokumen fisik yang disimpan disuatu tempat terkadang memerlukan waktu yang cukup lama untuk menemukan dan meminjam dokumen yang dibutuhkan. Aplikasi Document Management System (DMS) menjadi salah satu pemecah masalah yang cukup handal untuk menyelesaikan berbagai macam permasalahan tentang pengarsipan dokumen. Pada pembuatan aplikasi DMS berbasis website menggunakan bahasa pemograman Hypertext Preprocessor (PHP), dengan framewok Laravel dan Postgres sebagai database tempat penyimpanan data dan menggunakan metode Waterfall. Penerapan DMS yang didukung oleh aplikasi berbasis website menjadikan aplikasi yang dapat diakses dimanapun dan kapanpun, dokumen yang tersimpan secara terpusat, dan mudahnya mengakses data antar bidang.
\end{abstract}

Kata Kunci : Data, Document Management System,, Waterfall.

\begin{abstract}
One of the most important assets in supporting every work program implemented at the National University community is document management. In the current process, the organization will certainly produce data or documents that are not small with a variety of criteria. The number of physical documents stored in a place sometimes takes a long time to find and borrow the documents needed. The Document Management System (DMS) application is one of the problem solvers that is reliable enough to solve various problems regarding document archiving. In making a website-based DMS application using the Hypertext Preprocessor (PHP) programming language, with the Laravel and Postgres framewok as a database for storing data and using the Waterfall method. The application of $D M S$ which is supported by a website-based application makes the application accessible wherever and whenever, documents are stored centrally, and easily access data between fields.
\end{abstract}

Key Words: Data, Document Management System,, Waterfall

\section{PENDAHULUAN}

Seiring dengan perkembangan zaman dan arus globalisasi budaya masyarat di bidang informatika, komputer yang akan terus yang semakin berkembang dalam waktu yang singkat hal ini menyebabkan kebutuhan untuk mendapatkan informasi dengan mudah, cepat dan aman juga semakin meningkat. Pada dasarnya teknologi informasi dikembangkan untuk mempermudah mendapatkan informasi dan data yang dibutuhkan. Kumpulan dokumen fisik dengan jumlah yang sangat besar tentunya bukan pekerjaan mudah untuk dikelola. Karena masalah tersebut saat ini diperlukan sebuah metode yang dapat mengklasifikasi dan mengorganisir dokumen secara digital dan otomatis, sehingga diharapkan dapat mempermudah dalam pencarian informasi yang diinginkan. Dengan memanfaatkan kemajuan yang pesan dibidang Teknologi 
dan Informasi diharapkan dapat mempermudah dalam pekerjaan, pengolahan data - data penting, peminjaman dan pengembalian dokumen dengan mudah, cepat dan aman. Banyak dokumen yang tidak tersusun rapi dan tidak terpusat di suatu tempat sehingga membutuhkan waktu lebih lama untuk mencari dokumen yang diinginkan. Hal inilah yang melatar belakangi penelitian ini.

Universitas Nasional adalah perguruan tinggi kedua tertua di Indonesia dan perguruan tinggi swasta yang tertua di Jakarta, dengan keadaan manajemen dokumen saat ini Universitas Nasional memerlukan adanya aplikasi yang dapat mengatur seluruh dokumen yang berada di Universitas Nasional untuk mempermudah dalam pencarian dan peminjaman dokumen serta meminimalisasi terjadinya dokumen hilang atau rusak dikarenakan human error.

Sistem yang dikembangkan ini akan menggunakan metode waterfall yang dimana analisis kebutuhan yang sudah jelas sehingga tidak ada pengulangan pada tahap yang ada apabila ada kesalahan maka harus diulangi dari awal, selain itu pada tahap ini dilakukan pengembangan sistem seperti penambahan fungsionalitas baru [1].

Aplikasi DMS dirancang untuk memenuhi kebutuhan dari Universitas Nasional. Perancangan pada dasarnya telah dideskripsikan sebagai proses proses banyak langkah dimana representasi representasi data dan struktur program, katarteristik antarmuka, dan rincian prosedural yang berkaitan dengan kebutuhan informasi [3].

Sistem ini akan digambarkan pemodelannya menggunakan pemodelan Unified Modeling Language yang mana terdapat beberapa tipe diagram, antaranya adalah Sequence Diagram terdiri atas diagram untuk actor dan use case, Use Case Diagram. Pada pembuatan sequence diagram terdapat bebarapa simbol yang digunakan dalam proses pembuatan seperti aktor, object lifeline. Pada sistem diperlukan penggambaran struktur mulai dari segi pendefinisian class yang akan dikembangkan yang memiliki attribute, metode dan operasi merupakan fungsi Class Diagram.

Tujuan dari pembuatan aplikasi Document Management System (DMS) ini adalah untuk menghasilkan suatu sistem perangkat lunak untuk memudahkan Universitas Nasional dalam tata kelola dan pengarsipan dokumen perusahaan diseluruh wilayah Universitas Nasional. Pada aplikasi Document Management System (DMS) akan dapat menyimpan seluruh dokumen yang telah diupload, menyimpan history versioning dari sebuah dokumen, meminjam dan mengembalikan dokumen, dan menyimpan data yang berelasi antar dokumen.

Persetujuan antar level user akan terjadi ketika proses peminjaman pada aplikasi DMS. Workflow adalah suatu proses kerja yang aplikasiatis dimana dokumen yang dipinjam dialhirkan dari satu pihak ke pihak yang lain untuk ditindak lanjuti [2].

\section{METODE PENELITIAN}

Metode pengembangan perangkat lunak yang paling sering digunakan adalah metode waterfall Model yang digunakan pada metode waterfall adalah model klasik yang sifatnya aplikasiatis, berurutan dalam membangun aplikasi perangkat lunak. Dikarenakan tahap demi tahap yang dilalui harus menunggu selesai tahap sebelumnya dan berjalan berurutan disebut dengan waterfall [2]. Adapun langkah langkah - pengembangan metode waterfall ini digambarkan sebagai berikut : 


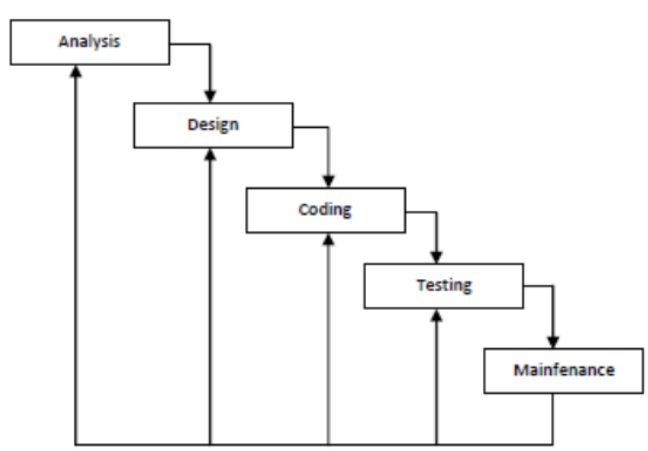

Gambar 1. Tahapan Metode Waterfall

Penjelasan tahapan - tahapan di atas dengan rincian sebagai berikut :

1. Analisis

Pada tahap pertama dilakukan analisa kebutuhan aplikasi atas sistem aplikasi yang saat ini sedang berlaku dengan merancang sistem yang baru, Berdasarkan konsultasi dengan pengguna maka dihasilkan kendala yang dihadapi, menetapkan tujuan dan layanan system aplikasi yang kemudian didefinisikan secara detail dan berfungsi sebagai spesifikasi system Document Management System.

\section{Design}

Setelah tahap pertama selesai, tahap kedua ini sebagian besar kegiatan dilakukan oleh komputer. Spesifikasi perangkat lunak dan keras yang telah disusun pada tahap analisis akan ditinjau kembali berikut tentang programnya. Pada tahap ini pula user yang menggunakan system melakukan latihan untuk pertama kalinya, pengetesan aplikasi dilalukan secara menyeluruh dan apabila pengguna sistem telah puas melihat hasil testing yang telah dilakukan maka proses selanjutnya adalah memulai persetujuannya untuk tahap selanjutnya[3].

\section{Coding}

Setelah melalui tahapan analisis dan perancangan design, maka sebuah sistem aplikasi siap untuk diimplementasikan. Design dalam bentuk source code, script dan sebagainya menjadi tahapan implementasi. Pengembangan seperti kebutuhan database dan dinilai mencukupi untuk mendukung sistem informasi DMS maka pada tahap selanjutnya penulis melakukan pembuatan pemasukan dan keluaran sistem informasi DMS pada Universitas Nasional berbasis web dengan menggunakan PostgreSQL sebagai tempat penyimpanan data dan bahasa pemrogaraman PHP dengan framework Laravel.

\section{Testing}

Setelah tahap pengkodean berjalan dengan baik dan telah selesai maka akan dilakukan testing terhadap system aplikasi Document Management System yang telah dibangun. Pengetesan bertujuan untuk menemukan kesalahan - kesalahan pada sistem dan kemudian dapat diperbaiki sehingga kesalahan yang terjadi hilang atau berkurang.

\section{Operation \& Maintenance}

Pada tahap ini pemeliharaan atau maintenance terdapat dua tahap review yang harus dilakukan. Penerapan pertama kali dilakukan tidak terlalu lama setelah penerapan system dimulai, dimana masing - masing anggota masih memiliki ingatan segar atas sistem yang mereka buat dan angota yang mengerjakan aplikasi masih lengkap dan. Penerapan review atau maintenance berikutnya dapat dilaksanakan setelah enam bulan aplikasi berjalan.

Kelebihan dari Metode waterfall adalah kerangka yang dapat bisa dimengerti dengan mudah, dimana di dalam kerangka tersebut terdapat proyek yang memiliki tipe dan strategi yang berbeda-beda [4].

Metode waterfall juga mempunyai kekurangan yaitu metode ini tidak memungkinkan untuk banyaknya revisi jika terjadi kesalahan dalam proses pembuatannya, dikarenakan setelah aplikasi ini dalam tahap pengujian atau testing, sulit untuk mengubah sesuatu yang tidak terdokumentasi dengan baik, dan akan susah kembali lagi ke proses sebelumnya. 


\section{HASIL DAN PEMBAHASAN}

Pada hasil dan pembahasan ini dilakukan implementasi terhadap system aplikasi Document Management System. Setelah tahap perancangan selesai dilakukan dan selanjutnya diimplementasikan ke dalam bahasa pemrograman maka tahap implementasi dan pengjuian dilakukan. Setelah proses implementasi selesai maka dilakukan pengujian terhadap aplikasi yang baru untuk pengembangan system aplikasi selanjutnya.

Berikut adalah gambaran alur proses aplikasi DMS

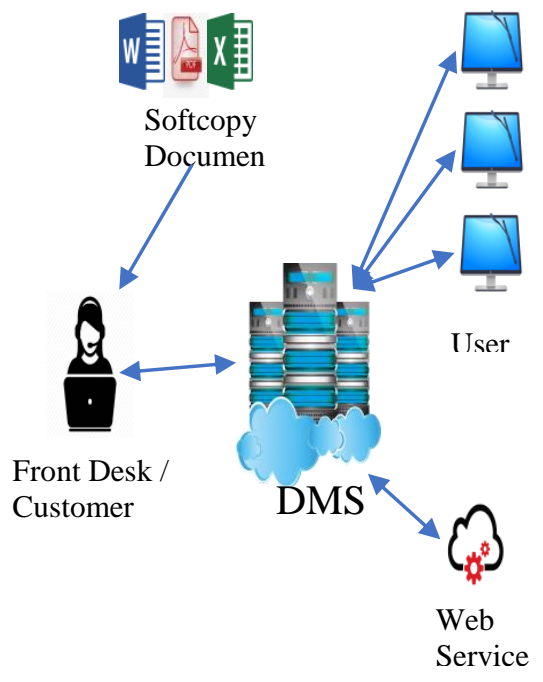

\section{Gambar 1. Alur Proses Aplikasi DMS}

Modul aplikasi untuk kebutuhan aplikasi DMS yang diperlukan harus memenuhi antara lain :

- Aplikasi Document Management System (DMS) berbasis web.

- Fitur dan hak akses disesuaikan dengan fakultas yang berlaku saat ini di Universitas Nasional.

- Dapat menambahkan, mengubah judul folder dan subfolder untuk wadah penyimpanan dokumen.

- Terdapat fitur meminjam dan mengembalikan dokumen.
- Storage : dengan teknologi database atau teknologi penyimpanan yang lainya, dan memiliki fasilitas penyimpanan dokumen yang terpusat pada satu aplikasi.

- Memiliki fitur version control yang dapat menyimpan history setiap versi dari sebuah dokumen setiap kali terjadi perubahan. Masing masing versi dokumen memiliki nomor identifikasi yang unik berupa nomor versi.

- Terdapat fitur related yang dapat melihat dokumen lain yang saling terkait.

- Keamanan : untuk mencegah terjadinya pengaksesan dokumen oleh yang tidak berhak maka diperlukan penerapan control akses dokumen yang dapat disesuaikan secara dinamis dengan hak dari grup dari pengguna tertentu,

- Searching dokumen

- Categorization : pengelompokan dokumen sesuai dengan struktur folder dan subfolder yang telah didaftarkan pada menu parameter.

- Terdapat fitur penempatan dokumen fisik(lokasi dokumen fisik)

Pengujian fungsi dasar sistem menggunakan balckbox manual testing 
Tabel 1. Pengujian Blackbox

\begin{tabular}{|l|l|l|l|l|}
\hline No & Fungsi & $\begin{array}{l}\text { Skenario } \\
\text { Pengujuian }\end{array}$ & $\begin{array}{l}\text { Hasil yang } \\
\text { didapatkan }\end{array}$ & Ket \\
\hline 1. & Login & $\begin{array}{l}\text { Login } \\
\text { menggunakan } \\
\text { username dan } \\
\text { password } \\
\text { yangsalah }\end{array}$ & $\begin{array}{l}\text { Menampilkan } \\
\text { pesan jika } \\
\text { username dan } \\
\text { password } \\
\text { salah }\end{array}$ & Valid \\
\hline 2. & $\begin{array}{l}\text { Dokumen } \\
\text { Upload }\end{array}$ & $\begin{array}{l}\text { Inputan } \\
\text { mandatory } \\
\text { dikosongkan }\end{array}$ & $\begin{array}{l}\text { Menampilkan } \\
\text { pesan wajib } \\
\text { diisi }\end{array}$ & Valid \\
\hline 3. & Dashboard & $\begin{array}{l}\text { Menampilkan } \\
\text { dashboard yang } \\
\text { interactive }\end{array}$ & $\begin{array}{l}\text { System } \\
\text { menampilkan } \\
\text { dashboard }\end{array}$ & Valid \\
\hline 4. & $\begin{array}{l}\text { Peminjaman } \\
\text { Dokumen }\end{array}$ & $\begin{array}{l}\text { Meminjam } \\
\text { Dokumen }\end{array}$ & $\begin{array}{l}\text { Sistem } \\
\text { menampilkan } \\
\text { list dokumen } \\
\text { yang sedang } \\
\text { dipinjam }\end{array}$ & Valid \\
\hline
\end{tabular}

\section{Implementasi Interface Program}

\section{Halaman Utama}

Halaman utama atau home page merupakan tampilan pertama pada saat website DMS, terdiri dari beberapa menu yaitu Login, Data, dan Frequently Asked Question. Dalam halaman utama terdapat pula 10 data paling terbaru.

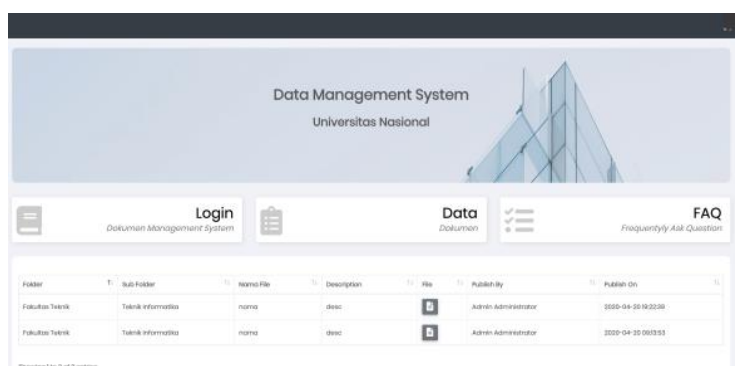

Gambar 2. Halaman Utama

\section{Halaman Login}

Tersedia menu login, berisi form input nama pengguna atau username dan kata sandi atau password.

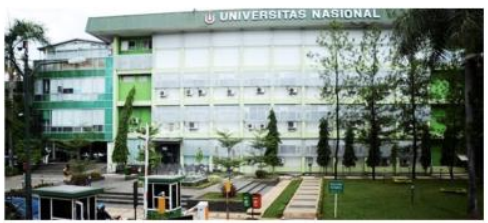

Gambar 3. Halaman Login

\section{Halaman Dashboard}

Data dalam bentuk grafik ditampilkan di halaman dashord.

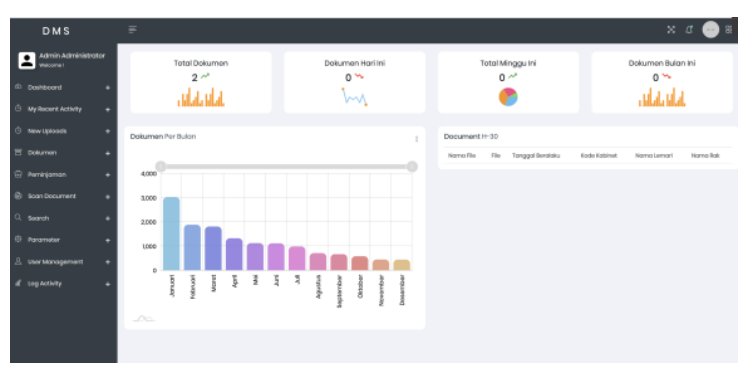

Gambar 4. Halaman Dashboard

\section{Halaman Upload Dokumen}

Inputan pada menu upload dokumen berupa : Folder, Subfolder, File, dan lain lain. Terdapat 2 jenis klasifikasi yaitu Publish dokumen dapat dilihat semua user, dan Private dokumen hanya dapat dilihat oleh user dengan fakultas yang sama.

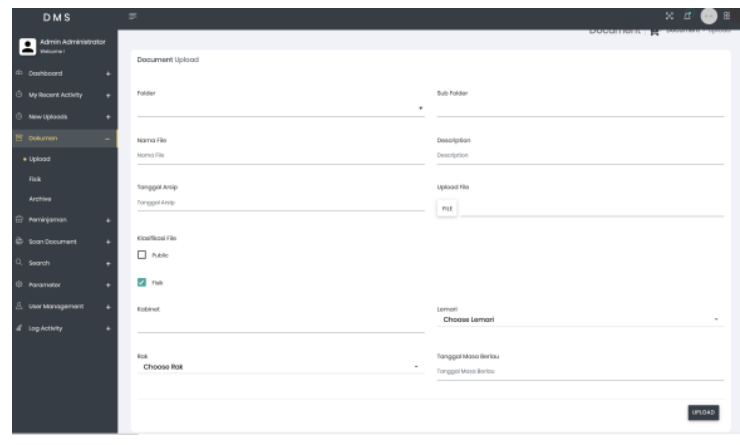

Gambar 5. Halaman Upload Dokumen 
5. Halaman View Data Related dan Data Versioning

Berikut adalah tampilan data related dan data versioning yang sudah diupload sebelumnya.

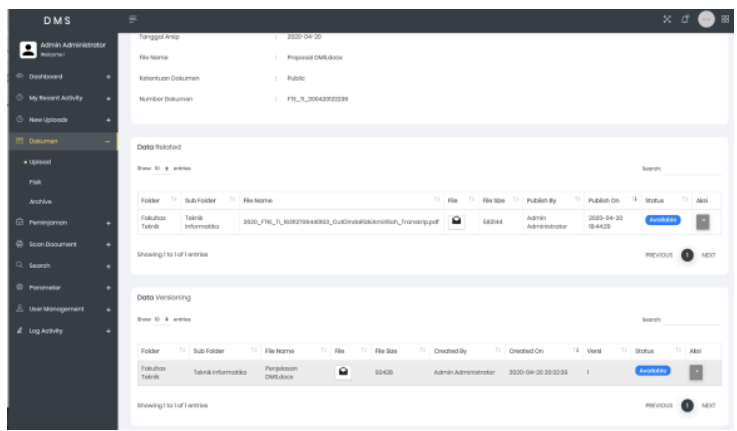

Gambar 6. Halaman View Data Related dan Data Versioning

6. Halaman Peminjaman Dokumen

Halaman ini berupa list dokumen yang berstatus publish dan dapat dipinjam.

Terdapat 2 sub menu yaitu Monitoring untuk melihat semua dokumen yang dipinjam.

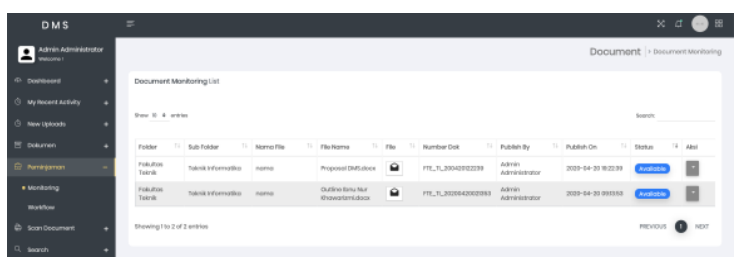

Gambar 7. Halaman Monitoring

Dan Sub Menu Workflow untuk meminjam dokumen.

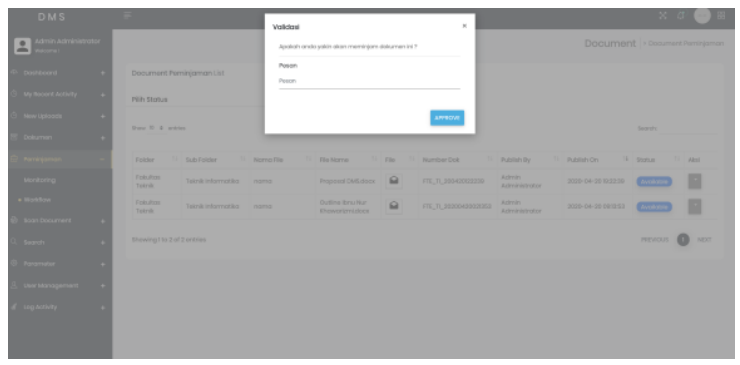

Gambar 8. Halaman Workflow

\section{Halaman User Management}

Terdapat 2 sub menu pada menu User Management yaitu Master User untuk mendaftarkan user yang dapat mengakses aplikasi DMS

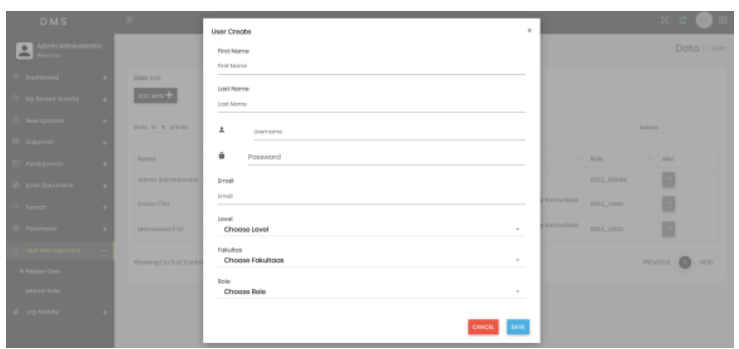

Gambar 9. Halaman Master User

Dan sub menu Master Role, untuk mencegah dokumen diakses oleh pihak yang tidak berhak maka disediakan menu Role. Menu ini diperuntukan untuk hak kontrol akses terhadap setiap dokumen yang dapat disesuaikan secara dinamis dengan hak dari grup pengguna tertentu.

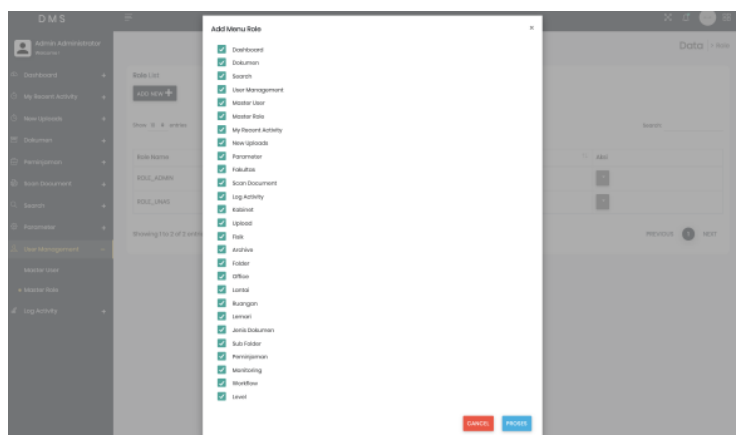

Gambar 10. Halaman Master Role

\section{Halaman Parameter}

Halaman ini berguna untuk menyetel beberapa parameter seperti Folder, Sub Folder, Kabinet, Office, Ruangan, Lantai dan sebagainya untuk keperluan aplikasi DMS 


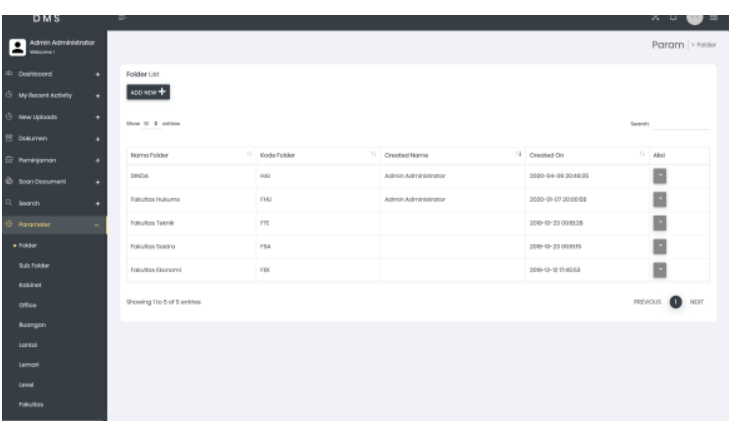

Gambar 11. Halaman Parameter Folder

\section{Halaman Log Activity}

Halaman ini menampilkan semua aktifitas user, biasanya digunakan untuk keperluan IT.

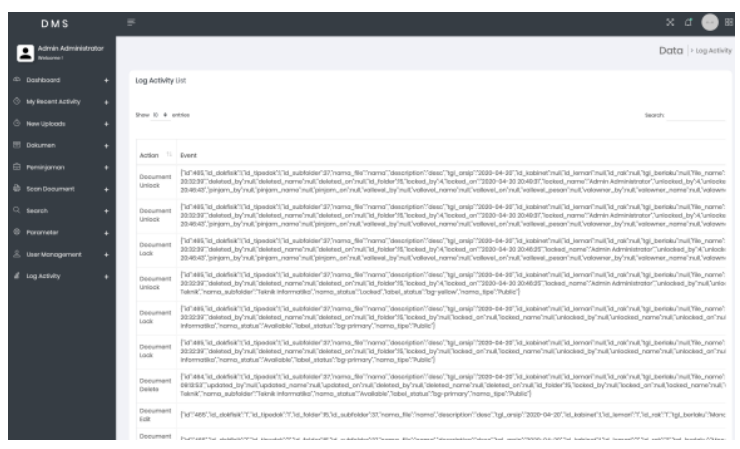

Gambar 12. Halaman Log Activity

\section{SIMPULAN}

\section{Simpulan}

Dari hasil implemantasi dan uji coba aplikasi Document Management System pada Universitas Nasional untuk pengelolaan data berbasis website maka kesimpulannya adalah sebagai berikut :

1. Aplikasi DMS dapat mengemas dokumen dengan rapi, peminjaman dokumen dapat dilakukan secara online, dan pencarian dokumen menjadi lebih praktis dan cepat.

2. Aplikasi Document Management System ini akan membantu dan mempermudah pengguna dalam pengarsipan berbagai jenis dokumen yang berada pada sivitas akademik Universitas Nasional.

\section{Saran}

Adapun saran dari hasil implentasi adalah : 1. Aplikasi Document Management System dapat dikembangkan secara mobile sehingga user dapat mengaksesnya menggunakan smartphone.

2. Aplikasi dapat mengeluarkan notifikasi berupa email secara berkala kepada user yang bersangkutan.

3. Aplikasi dapan men-scan dokumen secara real time.

\section{DAFTAR PUSTAKA}

[1] Cahyaningsih, Nike Wirahayu, Denny Sagita Rusdiato, and Komang Candra Brata. "Pengembangan Aplikasi Pengelolaan Dan Monitoring Perjalanan Dinas (Studi Kasus: SMK Canda Bhirawa Pare)." Jurnal Pengembangan Teknologi Informasi dan Ilmu Komputer e-ISSN 2548: 964X.

[2] Pramesti, Shelvi Damayana. TA: Pengembangan Rules Driven Workflow Management System pada Penerimaan Peserta Didik Baru Smk Ketintang Surabaya untuk Memudahkan Pengelolaan Data Berbasis Website. Diss. Universitas Dinamika, 2020.

[3] Irawati, Irawati. Perancangan Sistem Informasi E-Arsip Surat Pada Kantor DPRD Sengeti Kabupaten Muaro Jambi Berbasis Web. Diss. STIKOM Dinamika Bangsa Jambi, 2019.

[4] Atmini, Siti, Alexius Endy Budianto, and Moh Ahsan. "Analisis dan Pengembangan Sistem Informasi Tracer Study Menggunakan Metode Waterfall Berbasis Web." Semnas SENASTEK Unikama 20192 (2019).

[5] Lubis, Juanda Hakim, Rizki Muliono, and Nurul Khairina. "Perancangan Dan Implementasi Aplikasi Sistem Informasi Dokumentasi dan Pelaporan Dokumen Borang Akreditasi Program Studi Pada Universitas Medan Area Program Pkm Diya 2019." Jurnal 
Informatika Kaputama 4.1 (2020): 8390.

[6] Muslima, Andi Rifaatul. Analisis Perancangan Dokumen Manajemen Sistem Menggunakan Metode Web Development Life Cycle (Studi Kasus: PT. Telekomunikasi Indonesia, Tbk Divisi Sevice Operation). Diss. UNIVERSITAS BAKRIE, 2020.
[7] Rosadi, Muhammad Edya, and Muhammad Rais Wathani. "Perancangan Electronic Document Management System Berbasis Web Untuk Perguruan Tinggi (Studi Pada Universitas Islam Kalimantan)." Technologia: Jurnal Ilmiah 10.4 (2019): 244-250. 